\title{
РЕГУЛЮВАННЯ АЗОТНОГО I ВУГЛЕВОДНОГО ОБМІНУ В ОРГАНІЗМІ МОЛОДНЯКА ВЕЛИКОЇ РОГАТОЇ ХУДОБИ
}

Радчиков Василь Федорович доктор сільськогосподарських наук, професор РУП «Науково-практичний центр НАН Білорусі з тваринництва» ORCID: 0000-0003-4090-6635 E-mail: arud22222@gmail.com

Кот Олександр Миколайович кандидат сільськогосподарських наук, доцент РУП «Науково-практичний центр НАН Білорусі з тваринництва» ORCID: 0000-0003-0719-9166 E-mail: arud22222@gmail.com

Цай Віктор Петрович кандидат сільськогосподарських наук, доцент РУП «Науково-практичний центр НАН Білорусі з тваринництва» ORCID: 0000-0002-1603-557X E-mail: arud22222@gmail.com

Бесараб Геннадій Васильович науковий співробітник РУП «Науково-практичний центр НАН Білорусі з тваринництва» ORCID: 0000-0001-8154-4808 E-mail: arud22222@gmail.com

Джумкова Марина Валеріївна РУП «Науково-практичний центр НАН Білорусі з тваринництва» ORCID: 0000-0002-0362-3727

E-mail: 488dmv@gmail.com

Самохіна Євгенія Анатоліївна кандидат сільськогосподарських наук, доцент Сумський національний аграрний університет

ORCID: 0000-0002-0983-3047 E-mail: f_bt@sau.ua

Вивчено вплив екструдованої суміші концентратів з високим вмістом протеїну, що розщеплюється і неструктурних вуглеводів на показники рубцевого травлення, продуктивність і ефективність використання кормів раціонів. Дослідження проведені на 2-х групах бичків чорно-рябої породи у віці 3-6 місяиів. Крім комбікорму тварини контрольної групи отримували розмолоту суміш зерна ячменю і пелюшки, а в дослідній - екструдовану. Встановлено, що в середньому на добу піддослідний молодняк отримував 4,3-4,4 кә / голову сухої речовини раціону. Зміст обмінної енергії в сухій речовині раціону дослідної групи склало 10,1 МДж / ке. На частку сирого протеїну в сухій речовині раціонів становило 11,9\%. Кількість клітковини в сухій речовині не перевищувало 26\%. Екструдування концентрованих кормів сприяє збільшенню кількості протеїну, що не розщеплюється в раціоні на 23\%. Зәодовування бичками чорно-рябої породи у віці 3-6 місяців зерносуміші, підданої баротермічній обробиі, призводить до підвищення чисельності інфузорій в рубцевій рідині на 4,4 \%, загального азоту - на 8,3\%, зниження концентрації аміаку і летючих жирних кислот на 8,7 і 3,5 \% відповідно. Згодовування екстрадованої суміші зробило певний вплив на склад крові тварин. Так, у бичків дослідної групи відзначено підвищення вмісту еритроцитів на 4,0\%, гемоглобіну - на 3,9, загального білка - на 4,0 і фросфору - на 4,4\%. У той же час рівень глюкози знизився на 6,4\%, сечовини - на 2,0 і кальцію на 6,4\%. Проте зазначені відмінності були недостовірними. Більш високі прирости відзначені в II дослідній групі - 804 г на добу, що на 5,8\% вище, ніж в I. Витрати кормів в цій групі були нижче, ніж в першій на 3,2 \% і склали 5,7 корм. од. Таким чином, згодовування молодняку великої рогатої худоби зерносуміші, підданої баротермічній обробці, сприяє посиленню процесів травлення і обміну речовин в організмі, підвищенню продуктивності тварин на 5,8 \% і зниженню витрат кормів на 3,2 \%..

Ключові слова: молодняк великої рогатої худоби, зерно пелюшки, вики, розмол, подрібнення, продуктивність.

DOI: https://doi.org/10.32845/bsnau.Ivst.2021.2.21

Повноцінне білкове харчування жуйних передбачає забезпечення потреби організму тварини в доступних для

обміну амінокислотах. Однак дефіцит кормового білка і нераціональне його використання в організмі тварин приз- 
водять до того, що протеїн є одним з найважливіших факторів, що лімітують в системах інтенсивного виробництва молока і м'яса [1-7].

Високу продуктивність тварин реалізувати простим збільшенням в раціонах частки високобілкових кормів на практиці складно і не рентабельно. Такий підхід призводить не тільки до перевитрати кормів і подорожчання одержуваної продукції, а й негативно впливає на здоров'я тварин, як наслідок призводить до різкого скорочення терміну їх продуктивного використання [8-13].

Можливість регулювання ступеня розпаду протеїну в передшлунках, одним з яких є вплив високої температури є важливим питанням протеїнового харчування жуйних. Зни- ження розпадання протеїну без зміни його перетравності в кишечнику досягається при короткочасних впливах температури в межах 80-120 ㄷ. Технологічно теплова обробка білкових кормів може здійснюватися на підприємствах комбікормової і переробної промисловості шляхом автоклавування, тостування або пресування [14-18].

Мета роботи - вивчити вплив екструдованої суміші концентратів з високим вмістом розщеплюється протеїну і неструктурних вуглеводів на показники рубцевого травлення, продуктивність бичків у віці 3-6 місяців.

Матеріали і методи досліджень. Дослідження проведені на 2-х групах бичків чорно-рябої породи у віці 3-6 місяців (таблиця 1).

Таблиця 1

\section{Схема проведення досліджень}

\begin{tabular}{|l|c|c|c|l|}
\hline \multicolumn{1}{|c|}{ Група } & $\begin{array}{c}\text { Кількість тварин, } \\
\text { гол. }\end{array}$ & $\begin{array}{c}\text { Вік тварин, } \\
\text { міс. }\end{array}$ & $\begin{array}{c}\text { Тривалість досліду, } \\
\text { днів }\end{array}$ & \multicolumn{1}{c|}{ Особливості згодовування (годівлі) } \\
\hline І дослідна & 3 & $3-6$ & 60 & ОР (мелена суміш концентратів) \\
\hline II дослідна & 3 & $3-6$ & 60 & ОР (екструдована суміш концентратів) \\
\hline
\end{tabular}

Відмінності в годівлі полягали в тому, що тварини контрольної групи отримували розмолоту суміш зерна ячменю і пелюшки, а в дослідній - екструдовану. Фізіологічні досліди по вивченню показників рубцевого травлення в багатокамерному шлунку проведенні на складнооперованних тваринах з імплантованими хронічними канюлями рубця.

Хімічний скад кормів визначався за схемою загального зоотехнічного аналізу в лабораторії біохімічних аналізів РУП "Науково-практичний центр НАН Білорусі по тваринництву" за загальноприйнятими методиками.

Кількісні та якісні параметри процесів рубцевого метаболізму визначали методом in vivo.

Розщеплення протеїну білкових кормів визначали за ГОСТ 28075-89. У нейлонові мішечки були закладені зразки концентрованих кормів. Період інкубації концентрованих кормів, що досліджують у рубці склав: 2, 4, 6, 8 та 12 годин.

Статистична обробка результатів досліджень проведена з урахуванням критерію достовірності за Стьюдентом.

Результати досліджень та їх обговорення. Дослідженнями встановлено, що силос тварини отримували без обмежень. В структурі раціону на долю концентрованих кормів припадало 36 \% за поживністю. Трав'яні корми в структурі раціону займали $64 \%$. Концентровані корми тварини з'їдали повністю.

Піддослідний молодняк отримував 4,3 - 4,4 кг/голову за добу сухої речовини раціону. Вміст обмінної енергії в сухій речовині раціону дослідної групи склало 10,1 МДж/кг. На долю сирого протеїну в сухій речовині раціонів припадало $11,9 \%$. Перетравність протеїну в раціоні контрольної групи склала 80 \%, а в дослідній - 76 \%. Кількість клітковини в сухій речовині не перевищувало $26 \%$.

Дослідженнями встановлено, що в рубці тварин, які отримували екструдовану зерносуміш, вміст загального азоту виявився вищим на 8,3 \%, а аміаку нижче на 8,7 \% (табл. 2).

Рідина, що знаходиться в рубці тварин дослідної групи рівень летких жирних кислот також зменшився на 3,5 $\%$. Зниження кількості аміаку та збільшення загального білку може свідчити про те, що інтенсивність синтезу мікробного білку збільшилась внаслідок більш рівномірного надходжен- ня поживних речовин у рубець і створення більш благоприємних умов для життєдіяльності мікрофлори. Так, кількість інфузорій у другій групі збільшилось на 4,4%. Реакція середовища рубця рН у всіх групах майже суттєво не змінилась і знаходилась на рівні 6,04-6,18.

Таблиця 2

Параметри рубцевого травлення

\begin{tabular}{|l|c|c|}
\hline \multirow{2}{*}{ Показник } & \multicolumn{2}{c|}{ Група } \\
\cline { 2 - 3 } & $\mathrm{I}$ & $\mathrm{I}$ \\
\hline $\mathrm{pH}$ & $6,04 \pm 0,16$ & $6,18 \pm 0,18$ \\
\hline ЛЖК, ммоль/100 мл & $10,6 \pm 0,40$ & $10,23 \pm 0,18$ \\
\hline Азот загальний, мг/100 мл & $134,5 \pm 14,5$ & $145,7 \pm 14,89$ \\
\hline Аміак, мг/100 мЛ & $13,8 \pm 0,6$ & $12,6 \pm 0,40$ \\
\hline Інфузоріі, тис./мл & $799 \pm 13,5$ & $833 \pm 21,8$ \\
\hline
\end{tabular}

Але, незважаючи на деякі зміни в протіканні процесів травлення в рубці тварин, всі показники знаходились в межах норми.

Як показали дослідження, гематологічні показники знаходились в межах фізіологічних норм (табл. 3).

Таблиця 3

Гематологічні показники

\begin{tabular}{|l|c|c|}
\hline \multirow{2}{*}{\multicolumn{1}{|c|}{ Показник }} & \multicolumn{2}{c|}{ Група } \\
\cline { 2 - 3 } & $\mathrm{I}$ & $\mathrm{I}$ \\
\hline Еритроцити, $10^{12} / л$ & $6,24 \pm 0,13$ & $6,49 \pm 0,12$ \\
\hline Лейкоцити, $10^{9} / л$ & $10,05 \pm 0,25$ & $10,23 \pm 0,49$ \\
\hline Гемоглобін, г/л & $106,1 \pm 6,3$ & $110,2 \pm 4,51$ \\
\hline Загальний білок, г/л & $75,75 \pm 2,25$ & $78,77 \pm 1,56$ \\
\hline Глюкоза, ммоль/л & $2,49 \pm 0,16$ & $2,33 \pm 0,03$ \\
\hline Сечовина, ммоль/л & $4,1 \pm 0,14$ & $4,02 \pm 0,14$ \\
\hline Кальцій, ммоль/л & $2,82 \pm 0,12$ & $2,64 \pm 0,06$ \\
\hline Фосфор, ммоль/л & $1,59 \pm 0,15$ & $1,66 \pm 0,05$ \\
\hline Гематокрит, \% & $34,55 \pm 1,85$ & $34,73 \pm 1,22$ \\
\hline
\end{tabular}

Використання в годівлі ектрудованої суміші виявило певний вплив на склад крові тварин. Так, у бичків дослідної групи відмічали підвищений вміст еритроцитів на 4,0\%, гемоглобіну - на 3,9, загального білку - на 4,0 і фросфору на $4,4 \%$.

В той же час рівень глюкози знизився на $6,4 \%$, сечовини - на 2,0 та кальцію на 6,4\%. Проте зазначені відмінності були недостовірними.

Згодовування екструдованої суміші зерна пелюшки і ячменю замість меленої, сприяло підвищенню енергії роста 
та ефективності використання поживних речовин раціону | (табл. 4)

Таблиця 4

Динаміка живої маси та ефективність використання кормів піддослідним молодняком

\begin{tabular}{|l|c|c|}
\hline \multicolumn{1}{|c|}{ Показники } & \multicolumn{2}{|c|}{ Група } \\
\cline { 2 - 3 } $\begin{array}{l}\text { Жива маса, кг } \\
\text { на початку досліду }\end{array}$ & $132,7 \pm 1,3$ & $133,1 \pm 1,80$ \\
\hline в кінці досліду & $178,3 \pm 3,5$ & $181,3 \pm 2,40$ \\
\hline Валовий приріст, кг & $45,6 \pm 2,2$ & $48,2 \pm 10$ \\
\hline Середньодобовий приріст, г & $760 \pm 37$ & $803,3 \pm 17,7$ \\
\hline у \% до контролю & 100 & 105,7 \\
\hline Затрати кормів на 1 кг приросту, корм. од. & 5,89 & 5,70 \\
\hline у \% до контролю & 100 & 96,8 \\
\hline Затраты протеина на 1 кг приросту, кг & 0,68 & 0,66 \\
\hline у \% до контролю & 100 & 97,1 \\
\hline
\end{tabular}

У тваринах II дослідної групи відмічені більш високі прирости живої маси - 804 г за добу, що на 5,8\% вище, ніж в I групі. Затрати кормів в цій групі були нижче, ніж в першій на $3,2 \%$ і склали 5,7 корм. од.

Ефективність використання протеїну кормів також збільшилась на 3,0 \%.

Висновок. Обробка концентрованих кормів методом екструдування сприяє збільшенню кількості нерозщеплюваного протеїну в раціоні на $23 \%$. Згодовування тваринам зерносуміші, яка піддана баротермічній обробці, призводить до підвищення численності інфузорій в рубцевій рідині на 4,4 \%, загального азоту - на 8,3 \%, зниженню концентрації аміаку та летких жирних кислот на 8,7 і 3,5 \%відповідно, збільшенню вмісту еритроцитів у крові на 0,4\%, гемоглобіну - на 3,9, загального білку - на 4,0 і фросфрору - на 4,4 \%. Зменшення сечовини - на 2,0 і кальцію - на 6,4 \%. В дослідній групі середньодобовий приріст живої маси підвищився на 5,8\%, при зниженні затрат кормів на його отримання на 3,2 \%.

\section{Список використаної літератури:}

1. Нормы скармливания жмыха и шрота из семян новых сортов рапса молодняку крупного рогатого скота / Радчиков В. Ф., Горлов И. Ф., Сложенкина М. И., Сапсалёва Т. Л., Цай В. П., Кот А. Н., Бесараб Г. В., Люндышев В. А., Натынчик Т. М., Приловская Е. И. // Научно-практический центр Национальной академии наук Беларуси по животноводству. Жодино, 2019.

2. Повышение продуктивного действия кукурузного силоса за счет включения комплексных кормовых добавок / Натынчик Т. М., Космович Е. Ю., Савенков О. И., Макаревич Я. В.// Биотехнология: достижения и перспективы развития. Сборник материалов III международной научно-практической конференции. Шебеко К.К. (гл. редактор). 2018. С. 59-62.

3. Богданович Д. М. Кремнезёмистые и карбонатные сапропели в рационах молодняка крупного рогатого скота / Д. М. Богданович // Модернизация аграрного образования: интеграция науки и практики. Сборник научных трудов по материалам V Международной научно-практической конференции. Жодино, 2019. - С. 216 - 219.

4. Натынчик Т. М., Натынчик Г. Г. Инновационные подходы в подготовке кормов к скармливанию для крупного рогатого скота / Т. М. Натынчик, Г. Г. Натынчик // Биотехнология: достижения и перспективы развития. Сборник материалов I международной научно-практической конференции. 2014. - С. 93 - 96.

5. Показатели рубцового пищеварения у молодняка крупного рогатого скота в возрасте 6 - 9 месяцев от скармливания экструдированных высокобелковых концентрированных кормов/ Кот А. Н., Мосолова Н. И., Бесараб Г. В., Антонович А. М., Долженкова Е. А., Сапсалёва Т. Л., Радчикова Г. Н., Жалнеровская А. В., Астренков А. В., Приловская Е. И. // Зоотехническая наука Беларуси, 2020. - Т. 55. - № 2. - С. 3 - 13.

6. Эффрективность использования 3ОМ с различным включением молочного сахара в комбикорме КР-2 для молодняка крупного рогатого скота / Г. Н. Радчикова, С. Н. Пилюк, С.В. Сергучев, А. Н. Кот, Л. А. Возмитель, М. М. Брошков, А. В. Данчук, С. Г. Стояновский, Л.М.Дармаграй // Актуальні проблеми підвищення якості та безпека виробництва й переробки продукціі тварнництва. Матеріали міжнародноі науково-практичноі конференціі (14 лютого 2020 року), Дніпро, 2020. - С. 6265

7. Влияние количества протеина в составе заменителей цельного молока на продуктивность телят в возрасте 10-30 дней / Г. Н. Радчикова, А. Н. Кот, Н. А. Яцко, Н. А. Шарейко, Л .А. Возмитель, В. В. Букас, И. В. Сучкова // Вісник Сумьского національного аграрного університету. Серія «Тваринництво». - Вип. 2 (34), 2018. - С. 209 - 213

8. Эффрективность скармливания коровам осоложенного зерна / Разумовский С. Н., Кот А. Н., Радчикова Г. Н., Сапсалёва Т. Л., Богданович Д. М. // От инерции к развитию: научно-инновационное обеспечение развития животноводства и биотехнологий. Сборник материалов международной научно-практической конференции "От инерции к развитию: научноинновационное обеспечение АПК", 2020. - С. 177-179.

9. Зависимость рубцового пищеварения и эффективности использования кормов молодняком крупного рогатого скота от степени измельчения зерна бобовых / Натынчик Т.М., Космович Е. Ю., Савенков О. И., Макаревич Я. В. // Биотехнология: достижения и перспективы развития. Сборник материалов III международной научно-практической конференции, 2018. C. $62-64$.

10. Влияние "защиты" протеина на эффективность использования корма молодняком крупного рогатого скота / Кот А.Н., Бесараб Г.В., Антонович А.М. // Научное обеспечение животноводства Сибири. Материалы II международной научно- 
практической конференции. Красноярский научно-исследовательский институт животноводств. - Обособленное подразделение «Федерального исследовательского центра «Красноярский научный центр Сибирского отделения Российской академии наук»; Составители : Л. В. Ефимова, Т. В. Зазнобина. - 2018. - С. 148 - 152.

11. Богданович Д. М., Разумовский Н. П. Природный микробный комплекс в кормлении молодняка крупного рогатого скота / Д. М. Богданович, Н. П. Разумовский // Инновационное развитие аграрно-пищевых технологий. Материалы Международной научно-практической конференции. Под общей редакцией И. Ф. Горлова. - 2020. - С. 22 - 26.

12. Эффеективность скармливания зерна рапса, люпина, вики, гороха в рационах телят / В. П. Гурин, В. П. Цай, А. Н. Кот, Г. Н. Радчикова, А. Н. Шевцов // Розведення і генетика тварин, 2012. - № 46. - С. 322 - 325.

13. Антонович А. М., Бесараб Г. В. Комбикорма с экструдированным люпином для молодняка крупного рогатого скота / А. М. Антонович, Г. В. Бесараб // Новые подходы к разработке технологий производства и переработки сельскохозяйственной продукции. Материалы Международной научно-практической конференции. Под общ. ред. И.Ф. Горлова . - 2018. - С. 72 76.

14. Богданович Д. М., Разумовский Н. П. Эффрективность скармливания телятам кормовой добавки "ПМК" / Д. М. Богданович, Н. П. Разумовский // Научные основы производства и обеспечения качества биологических препаратов для АПК. Материалы Международной научно-практической конференции, посвященной 50-летию института. Под редакцией А. Я. Самуйленко. - 2019. - С. 401 - 405.

15. Антонович А. М. Эффективность скармливания комбикорма с включением гранулированного люпина при производстве говядины/ А. М. Антонович // Актуальні питання технології продукції тваринництва. Збірник статей за результатами III Всеукраїнської науково-практичної інтернет-конференції. Полтавська державна аграрна академія. - 2018. - С. 118 - 123.

16. Богданович Д. М., Разумовский Н. П. Эффективность включения в рацион бычков новой кормовой добавки / Д.М. Богданович, Н.П. Разумовский //Селекционно-генетические и технологические аспекты производства продуктов животноводства, актуальные вопросы безопасности жизнедеятельности и медицины. Материалы международной научнопрактической конференции посвященной 90-летнему юбилею биотехнологического факультета. - 2019. С. 75-80.

17. Антонович А. М., Бесараб Г. В. Рубцовое пищеварение и расщепляемость протеина высокобелковых кормов в рубце в зависимости от способа обработки/ А. М. Антонович, Г. В. Бесараб// Современные технологии сельскохозяйственного производства. Сборник научных статей по материалам XXI Международной научно-практической конференции. Ответственный за выпуск В. В. Пешко. 2018. С. 118 - 120.

18. Эффеективность разных способов подготовки зерна к скармливанию / Г. В. Бесараб, А. М. Антонович, В. А. Голубицкий, В. В. Букас, В.В.Карелин, В.Н.Куртина// Актуальні питання технології продукції тваринництва. Збірник статей за результатами III Всеукраїнської науково-практичної інтернет-конференції. Полтавська державна аграрна академія. 2018. С. 123-127.

\section{References:}

1. Radchikov V. F., Gorlov I. F., Slozhenkina M. I., Sapsalyova T. L., Tsai V. P., Kot A. N., Besarab G.V., Lyundyshev V. A., Natynchik T. M., Prilovskaya E. I. 2019. Normy skarmlivanija zhmyha i shrota iz semjan novyh sortov rapsa molodnjaku krupnogo rogatogo skota: monogr. [Standards for feeding oil cake and meal from seeds of new rapeseed varieties to young cattle: monography]. Zhodino, $132 \mathrm{p}$.

2. Natynchik TM, Kosmovich E. Yu., Savenkov OI, Makarevich Ya. V. 2018. Povyshenie produktivnogo dejstvija kukuruznogo silosa za schet vkljuchenija kompleksnyh kormovyh dobavok [Increase of the productive action of corn silage due to the inclusion of complex feed additives]. In: Biotechnology: achievements and development prospects: collection of articles. materials of the III international scientific and practical conference, Pinsk, pp. 59-62.

3. Bogdanovich D. M. 2019. Kremnezjomistye i karbonatnye sapropeli v racionah molodnjaka krupnogo rogatogo skota [Silica and carbonate sapropels in the diets of young cattle]. In: Modernization of agricultural education: integration of science and practice. Collection of scientific papers based on the materials of the V International Scientific and Practical Conference, Tomsk, 5 December 2019. Tomsk-Novosibirsk, pp. 216-219.

4. Natynchik T. M., Natynchik G. G. 2014. Innovacionnye podhody v podgotovke kormov k skarmlivaniju dlja krupnogo rogatogo skota. In: Biotechnology: achievements and development prospects: collection of articles. materials of the III international scientific and practical conference, Pinsk, pp. 93-96.

5. Kot A. N., Mosolova N. I., Besarab G. V., Antonovich A. M., Dolzhenkova E. A., Sapsaljova T. L., Radchikova G. N., Zhalnerovskaya A. V., Astrenkov A. V., Prilovskaya E. I. 2020. Pokazateli rubcovogo pishhevarenija u molodnjaka krupnogo rogatogo skota v vozraste 6-9 mesjacev ot skarmlivanija jekstrudirovannyh vysokobelkovyh koncentrirovannyh kormov [Indicators of cicatricial digestion in young cattle at the age of 6-9 months from feeding extruded high-protein concentrated feed]. Zootehnicheskaja nauka Belarusi. Zhodino, Vol. 55, part 2, pp. 3-13.

6. Radchikova G. N., Pilyuk S. N., Serguchev S. V., Kot A. N., Vozmitel' L. A., Broshkov M. M., Danchuk A. V., Stoyanovsky S. G., Darmagray L. M. 2020. Jeffektivnost' ispol'zovanija ZOM s razlichnym vkljucheniem molochnogo sahara v kombikorme KR-2 dlja molodnjaka krupnogo rogatogo skota [Efficiency of using ZOM with different inclusions of milk sugar in the KR-2 compound feed for young cattle]. In: Actual problems of quality improvement and safety of production and processing of livestock products: materials of the international scientific-practical conference, February 14, 2020 Dnipro, pp. 62-65.

7. Radchikova G. N., Kot A. N., Yatsko N. A., Sharejko N. A., Vozmitel' L. A., Bukas V. V., Suchkova I. V. 2018. Vlijanie kolichestva proteina v sostave zamenitelej cel'nogo moloka na produktivnost' teljat v vozraste 10-30 dnej [Influence of the amount of protein in the composition of whole substitutes milk on the productivity of calves aged 10-30 days]. Visnyk Sumskoho NAU. Seriia 
«Tvarynnytstvo», issue 2(34), pp. 209-213.

8. Razumovsky S. N., Kot A. N., Radchikova G. N., Sapsalyova T. L., Bogdanovich D. M. 2020. Jeffektivnost' skarmlivanija korovam osolozhennogo zerna [Efficiency of feeding cows with malted grain]. In: From inertia to development: scientific and innovative support for the development of animal husbandry and biotechnology: Proceedings of the International Scientific and Practical Conference "From Inertia to Development: Scientific and Innovative Support of AIC", Yekaterinburg, February 18-19 2020, pp. 177179 .

9. Natynchik T. M., Kosmovich E. Ju., Savenkov O. I., Makarevich Ja. V. 2018. Zavisimost' rubcovogo pishhevarenija i jeffektivnosti ispol'zovanija kormov molodnjakom krupnogo rogatogo skota ot stepeni izmel'chenija zerna bobovyh [Dependence of cicatricial digestion and efficiency of feed use by young cattle on the degree of grinding of legumes]. In: Biotechnology: achievements and development prospects: collection of articles. materials of the III international scientific and practical conference, Pinsk, pp. 62-64.

10. Kot A. N., Besarab G. V., Antonovich A. M. 2018. Vlijanie "zashhity" proteina na jeffektivnost' ispol'zovanija korma molodnjakom krupnogo rogatogo skota [Influence of "protection" of protein on efficiency of use of a forage by young growth of cattle]. In: Scientific maintenance of animal husbandry of Siberia : materials of the II international scientific and practical conference, Krasnoyarsk, pp. 148-152.

11. Bogdanovich D. M., Razumovskij N. P. 2020. Prirodnyj mikrobnyj kompleks v kormlenii molodnjaka krupnogo rogatogo skota [Natural microbial complex in the feeding of young cattle]. In: Innovative development of agricultural and food technologies: materials of the International scientific-practical conference, Volgograd, pp. 22-26.

12. Gurin V. K., Tsai V. P., Kot A. N., Radchikova G. N., Shevtsov A. N. 2012. Jeffektivnost' skarmlivanija zerna rapsa, ljupina, viki, goroha v racionah teljat [Efficiency of feeding grain of rape, lupine, vetch, pea in the diets of calves]. Rozvedennia i henetyka tvaryn, no. 46. pp. 322-325.

13. Antonovich A. M., Besarab G. V. 2018. Kombikorma s jekstrudirovannym ljupinom dlja molodnjaka krupnogo rogatogo skota [Compound feed with extruded lupine for young cattle]. In: New approaches to the development of technologies for production and processing of agricultural products : materials of the International scientific-practical conference. Volgograd, pp. 72-76.

14. Bogdanovich D. M., Razumovsky N. P. 2019. Jeffektivnost' skarmlivanija teljatam kormovoj dobavki "PMK" [The effectiveness of feeding calves feed additive "PMK"]. In: Scientific bases of production and quality assurance of biological products for agriculture : materials of the International scientific-practical conference dedicated to the 50th anniversary of the institute, September 25-27, 2019, Shchelkovo, pp. 401-405.

15. Antonovich A. M. 2018. Jeffektivnost' skarmlivanija kombikorma s vkljucheniem granulirovannogo ljupina pri proizvodstve govjadiny [Efficiency of compound feed feeding with the inclusion of granulated lupine in beef production]. In: Current issues of technology of livestock products: a collection of articles on the results of the III All-Ukrainian scientific-practical Internet conference, Poltava, pp. 118-123.

16. Bogdanovich D. M., Razumovskij N. P. 2019. Jeffektivnost' vkljuchenija v racion bychkov novoj kormovoj dobavki [Efficiency of inclusion of a new feed additive in the diet of bull calves]. In: Selection-genetic and technological aspects of the production of livestock products, topical issues of life safety and medicine : materials of the international scientific-practical conference dedicated to the 90-year anniversary of the Faculty of Biotechnology. Vitebsk, pp. 75-80.

17. Antonovich A. M., Besarab G. V. 2018. Rubcovoe pishhevarenie i rasshhepljaemost' proteina vysokobelkovyh kormov v rubce $v$ zavisimosti ot sposoba obrabotki [Cicatricial digestion and degradability of protein in high-protein feeds in the rumen depending on the processing method]. In: Modern technologies of agricultural production : collection of scientific articles based on the materials of the XXI International Scientific and Practical Conference, Grodno, pp. 118-120.

18. Besarab G. V., Antonovich A. M., Golubickij V. A., Bukas V. V., Karelin V. V., Kurtina V. N. 2018. Jeffektivnost' raznyh sposobov podgotovki zerna k skarmlivaniju [The effectiveness of different methods of preparing grain for feeding]. In: Current issues of technology of livestock products : a collection of articles on the results of the III All-Ukrainian scientific-practical Internet conference. Poltava, pp. 123-127.

Radchykov Vasyl Fedorovych, Doctor Agricultural Sceiences, Professor

Kot A.N., CSc.(Agriculture), assistant professor,

Tsai Viktor Petrovych, CSc.(Agriculture), assistant professor,

Besarab Hennadii Vasylovych, Researcher

Dzhumkova Maryna Valeriivna, Researcher

Republican Unitary Enterprise «Scientific Practical Centre of Belarus National Academy of Sciences on Animal Breeding»,

Zhodino, Belarus

Samokhina Evgeniya Anatoliyivna, Ph.D. of Agricultural Sciences, docent

Sumy National Agrarian University (Sumy, Ukraine)

Regulation of nitrogen and carbohydrate metabolism in the body of young cattle

Effect of extruded mixture of concentrates with a high content of degradable protein and non-structural carbohydrates on indicators of rumen digestion, performance and efficiency of the dietary feed have been studied. Researches have been carried out with 2 groups of black-and-white steers at the age of $3-6$ months. In addition to compound feed, the animals of the control group received milled mixture of barley and field pea grain, and in the experimental group - extruded one. It has been determined that on average per day, the experimental young animals received 4,3-4,4 kg/animal of dietary dry matter. Metabolizable energy level in dry matter of diet in experimental groups made $10,1 \mathrm{MJ} / \mathrm{kg}$. The raw protein level in dry matter of diet made 11,9\%. The amount of fiber in dry matter did not exceed $26 \%$. Extrusion of concentrated feed increases the amount of non-degradable protein in diet by $23 \%$. 
Feeding steers of black-and-white breed at the age of 3 - 6 months with grain mixture after barothermal treatment leads to increase in the ciliates count in rumen fluid by $4,4 \%$, total nitrogen - by $8,3 \%$, decrease in concentration of ammonia and volatile fatty acids by 8,7 and 3,5\%, respectively. Feeding animals with extruded mixture had a significant effect on animals' blood composition. So, in steers of experimental group, increase in the erythrocytes level by 4,0\%, hemoglobin - by 3,9, total protein - by 4,0 and phosphorus - by $4,4 \%$ have been determined. At the same time, the level of glucose decreased by $6,4 \%$, urea - by 2,0 and calcium - by $6,4 \%$. However the differences above were unreliable. Higher weight gains have been determined in experimental group II - $804 \mathrm{~g}$ per day, which is $5,8 \%$ higher compared to the group I. Feed costs in this group were lower compared to the first one by $3,2 \%$ and amounted to 5,7 feed units. Thus, feeding young cattle with grain mixture after barothermal treatment enhances processes of digestion and metabolism in the body, increases performance of animals by $5,8 \%$ and reduces feed costs by $3,2 \%$.

Key words: young cattle, field pea grain, vetch grain, grinding, crushing, performance.

Дата надходження до редакції: 13.04.2021 р. 